\title{
Spring Is Here, but Contain Your Excitement
}

\author{
JOSEPH E. STIGLITZ
}

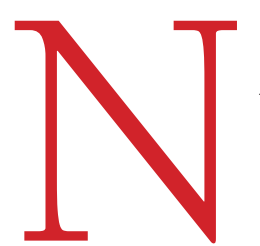

ew York-As spring comes to America, optimists are seeing "green sprouts" of recovery from the financial crisis and recession. The world is far different from what it was last spring, when the Bush administration was once again claiming to see "light at the end of the tunnel." The metaphors and the administrations have changed, but not, it seems, the optimism.

The good news is that we may be at the end of a free fall. The rate of economic decline has slowed. The bottom may be near-perhaps by

Joseph E. Stiglitz, Professor of Economics at Columbia University, chairs a Commission of Experts, appointed by the President of the U.N. General Assembly, on reforms of the international monetary and financial system. A new global reserve currency system is discussed in his 2006 book, Making Globalization Work.

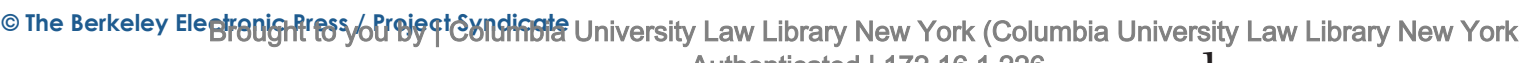

the end of the year. But that does not mean that the global economy is set for a robust recovery any time soon. Hitting bottom is no reason to abandon the strong measures that have been taken to revive the global economy.

This downturn is complex: an economic crisis combined with a financial crisis. Before its onset, America's debt-ridden consumers were the engine of global growth. That model has broken down, and will not be replaced soon. For, even if America's banks were healthy, household wealth has been devastated, and Americans were borrowing and consuming on the assumption that house prices would rise forever.

The collapse of credit made matters worse; firms, facing high borrowing costs and declining markets, responded quickly, cutting back inventories. Orders dropped abruptly-well out of proportion to the decline in GDP-and those countries that depended on investment goods and durables (expenditures that could be postponed) were particularly hard hit.

We are likely to see a recovery in some of these areas from the bottoms reached at the end of 2008 and the beginning of this year. But examine the fundamentals: in America, real estate prices continue to fall, millions of homes are underwater, with the value of mortgages exceeding the market price, and unemployment is increasing, with hundreds of thousands reaching the end of their 39 weeks of unemployment insurance. States are being forced to lay off workers as tax revenues plummet.

The banking system has just been tested to see if it is adequately capitalized-a "stress" test that involved no stress-and some couldn't pass muster. But, rather than welcoming the
The Economists' Voice May 2009 
opportunity to recapitalize, perhaps with government help, the banks seem to prefer a Japanese-style response: we will muddle through.

"Zombie" banks—dead but still walking among the living-are, in Ed Kane's immortal words, "gambling on resurrection." Repeating the Savings \& Loan debacle of the 1980's, the banks are using bad accounting (they were allowed, for example, to keep impaired assets on their books without writing them down, on the fiction that they might be held to maturity and somehow turn healthy). Worse still, they are being allowed to borrow cheaply from the United States Federal Reserve, on the basis of poor collateral, and simultaneously to take risky positions.

Some of the banks did report earnings in the first quarter of this year, mostly based on accounting legerdemain and trading profits (read: speculation). But this won't get the economy going again quickly. And, if the bets don't pay off, the cost to the American taxpayer will be even larger.

The American government, too, is betting on muddling through: the Fed's measures and government guarantees mean that banks have access to low-cost funds, and lending rates are high. If nothing nasty happens-losses on mortgages, commercial real estate, business loans, and credit cards-the banks might just be able to make it through without another crisis. In a few years time, the banks will be recapitalized, and the economy will return to normal. This is the rosy scenario.

But experiences around the world suggest that this is a risky outlook. Even were banks healthy, the deleveraging process and the associated loss of wealth means that, more likely than not, the economy will be weak. And a weak economy means, more likely than not, more bank losses.

The problems are not limited to the U.S. Other countries (like Spain) have their own real estate crises. Eastern Europe has its problems, which are likely to impact Western Europe's highly leveraged banks. In a globalized world, problems in one part of the system quickly reverberate elsewhere.

In earlier crises, as in East Asia a decade ago, recovery was quick, because the affected countries could export their way to renewed prosperity. But this is a synchronous global downturn. America and Europe can't export their way out of their doldrums.
Fixing the financial system is necessary, but not sufficient, for recovery. America's strategy for fixing its financial system is costly and unfair, for it is rewarding the people who caused the economic mess. But there is an alternative that essentially means playing by the rules of a normal market economy: a debt-for-equity swap.

With such a swap, confidence could be restored to the banking system, and lending could be reignited with little or no cost to the taxpayer. It's neither particularly complicated nor novel. Bondholders obviously don't like it - they would rather get a gift from the government. But there are far better uses of the public's money, including another round of stimulus.

Every downturn comes to an end. The question is how long and deep this downturn will be. In spite of some spring sprouts, we should prepare for another dark winter: it's time for Plan B in bank restructuring and another dose of Keynesian medicine.

Letters commenting on this piece or others may be submitted at submit.cgi? context=ev.

The Economists' Voice May 2009 